\title{
Introduction to the Special Issue on Creativity in Innovation
}

\section{Patrick Cohendet and Laurent Simon}

\author{
(6 Today... corporations spend a great deal of money and time") \\ trying to increase the originality of their employees... but \\ such programs make no difference unless management also \\ learns to recognize the valuable ideas among the many \\ novel ones, and then finds ways of implementing them. \\ Mihaly Csikszentmihalyi \\ Professor of Psychology and Management
}

\begin{abstract}
Managing creativity for innovation is a key challenge in today's economy; therefore, the management of ideas will play in increasing role in driving the growth and resilience of organizations. Rather than simple inspired insights, ideas have to be addressed as complex socio-cognitive processes, to be organized and managed. To benefit from the full value of new ideas, management must constantly balance the formal and the informal, the logic of creation and the logic of production, and must learn to couple idea-generation processes and innovation processes through renewed knowledge management practices. In this introduction to the Technology Innovation Management Review's special issue on Creativity in Innovation, the guest editors highlight the need to manage: i) ideation processes to foster creativity, ii) the tension that exists between the logic of creation and production; and iii) disruptive innovation to transform a traditional industry.
\end{abstract}

\section{Introduction}

Managing creativity in order to accelerate and improve innovation is the key management challenge that will be faced by companies in the coming years, and this challenge will be faced in an environment of ever-increasing complexity. These were the main findings of a recent face-to-face survey of $1500 \mathrm{CEOs,} \mathrm{general} \mathrm{man-}$ agers, and senior public sector leaders around the globe (IBM, 2010). The effects of rising complexity - hybridizing business issues with social, environmental, and ethical concerns - and the sudden convergence of digital, social, and mobile spheres, call for CEOs and their teams to lead with bold creativity, connect with customers in imaginative ways, and design their operations for speed, agility, and flexibility to position their organizations for sustainable success.

Business leaders across 16 sectors recognize creativity and innovation as their major challenges, and yet, they admit that they are not fully prepared to meet this chal- lenge, as discovered in a recent survey of business trends and challenges by Strategy\& (Rothfeder, 2015). The surveyed leaders identified three paths to explore in preparation for the upcoming evolution of business and markets: operational flexibility, two-way relationships with customers, and a greater focus on the medium-term future needs of customers. If social technologies, (big) data management, and analysis are going to play an important role in these transformations, then management - structure, processes, culture, and leadership - still has an essential role to play in setting up the right context for innovation to thrive.

The articles contributed to this special issue include many examples of actual drastic changes made by organizations attempting to cope with creative challenges. Managing creativity is a challenge for all the different functions of the enterprise and leads us to reconsider traditional ways of managing marketing, human resources, logistics, accounting, and finance, as well as strategy and planning. As a result, creative or- 


\section{Introduction to the Special Issue on Creativity in Innovation}

\section{Patrick Cohendet and Laurent Simon}

ganizations expect to make deeper internal changes in their operations, and to experiment with drastic, sometimes disruptive evolutions of their business model to realize their strategies. To succeed, they take more calculated risks, find new ideas, and keep innovating in how they lead and communicate internally and externally. Thus, embodying creative leadership, reinventing customer relationships, engaging customers as individuals and communities, building operational dexterity, empowering employees, amplifying innovation through partnerships, and unlocking a sense of community within the organization, are some of the emerging priorities put forward to transform existing organizations into creative and resilient businesses.

Not least among these characteristics are the paradoxes and tensions underlying the creation, production, marketing, and distribution of creative products. These tensions are particularly strong in specific industries, such as in the luxury goods industry, as Roberts and Armitage (2015) emphasize in their article in this issue. Because of the volatile and dynamic nature of the environment, firms must navigate through contradictory requirements and develop organizational solutions and innovative practices to survive and prosper (Eikhof \& Haunschild, 2007; Lampel \& Shamsie, 2000). Thus, many research studies have outlined different and sometimes paradoxical logics, ways of thinking, and knowledge and skills that coexist and co-evolve in the same firm or during the same development process. Paradoxes stemming from these industry features include tensions between creative and managerial controlling logics and values, diverging versus converging thinking, individual versus collective creativity, novelty versus familiarity in products, creativity versus rationalization (Caves, 2000).

In this special issue, we focus on some of these new perspectives followed by innovative organizations to cope with creative challenge. In particular, we focus on how to manage: i) ideation processes to foster creativity, ii) the tension that exists between the logic of creation and production; and iii) disruptive innovation to transform a traditional industry.

\section{Managing Ideation Processes to Foster Creativity}

As "new and useful combinations" (Drazin et al., 1999; Mednick, 1962; Woodman et al., 1993), ideas are the raw material of creativity and innovation. Organisations are generally rather efficient at generating new ideas, mostly through daily operations and vernacular experimentations (Styhre, 2006). Many creativity techniques, beyond brainstorming (Osborn, 1953) or lateral thinking (De Bono, 1971), have proven efficient in generating new, even disruptive ideas (bisociation: Koestler, 1964; the Triz method: Altshuller, 1984; the $\mathrm{C} / \mathrm{K}$ method: Le Masson et al., 2010), or in capturing new ideas from the inside out and from usages (crowdsourcing: Howe, 2008; design thinking: Brown, 2009, Verganti, 2009).

However, the emergence of new ideas is a necessary, yet insufficient condition for innovation. As underlined by Birkinshaw and colleagues (2011), ideas are mostly black boxes in innovation theories, which have to be addressed as processes. Idea management is a long, complex, and highly strategic process. Following the creative "spark" - the generation of the idea - the road ahead aims at maturating, challenging, enriching, and validating the insights. This conversion of the idea requires an investment in time, resources, and efforts in order to clearly identify, actualize, and extract the potential value of the idea. Mastering this conversion phase gives the organization a significant competitive advantage. This mastery could be defined as a strategic capability that cannot be delegated to the outside partners. It relies on specific internal procedures and leadership, and requires some hierarchical control. Throughout the literature, many researchers insist on the importance of transformation, conversion, maturation, and "valuation" for the development of ideas in innovative organizations (Block \& MacMillan, 1993, Christensen \& Raynor, 2003, Furr \& Dyer, 2014; Govindarajan \& Trimble, 2005).

Our own systematic studies of creative processes in different fields, times, and settings, from Cubism with Picasso, to Cirque du Soleil with Guy Laliberté and his creative team - as detailed by Simon (2015) in his article in this issue - or to the "techno-emotional" gastronomy of the restaurant with Ferran Adrià and his chefs - as analyzed by Capdevila, Cohendet, and Simon (2015) in their article in this issue - reveal the key role of two often underestimated artefacts: the codebook and the manifesto. The manifesto, explicit or not, asserts a strategic positioning in differentiation and values. It allows understanding of the idea as a converging vision that does not necessarily require constant coordination from a leader. It provides the creative collective with an agreement on the orientation of efforts, focusing on shared meaning and on a well-understood and accepted common purpose. What appears as a shared orient- 


\section{Introduction to the Special Issue on Creativity in Innovation}

\section{Patrick Cohendet and Laurent Simon}

ation in the symbolic dimension is completed by a systematic, more concrete effort to define the ways the idea is going to be used and exploited; its "grammar of use" is laid out in the codebook (Cowan et al., 2000). The codebook generally emerges from the projection of the creative intention into the realm of users: what they need to know and do in order to fully benefit from the new idea, once it has been concretized into a new product, service, or process. Often, prototyping will help in designing and refining the codebook. Both artefacts act as powerful complements to foster the understanding and acceptance of the idea by the hierarchy.

At the next step, when an idea reaches a sufficient degree of maturity - and there is an understanding of its possible functioning and potential value - the question at stake is its execution. Executing an idea supposes to organize its "landing" in pre-existing structures and processes. Formally, this signals the actual beginning of the innovation process itself, as defined, for instance, by Schumpeter himself $(1939,1942)$.

Hierarchy has a fundamental role to play in giving the "green light" to an idea when it reaches a certain level of ripeness. Officially endorsing and idea and starting a formal innovation process means keeping up with the enrichment, concretization, and valuation of the idea. The idea will benefit from internal and as well as external contributions, consciously channelled, managed, evaluated, and selected by management. Differing from the vision and metaphor of the innovation "funnel", ideas should not be considered only as quasi-material inputs to feed the innovation process. The evolution and actualization of ideas $i s$ the innovation process. In this regard, many innovative projects have encountered difficulty - when taking a sequential perspective - in recognizing, evaluating, transferring, and exploiting the new pieces of knowledge generated from the process. Generally, these insights are at worst forgotten, or at best, recaptured in complex intellectual property models, to be eventually franchised to external actors. Focusing on the idea generation, conversion, and execution process allows emphasis not only on the expected outputs (i.e., the deliverables and their exploitation/valuation model), but also on the outcomes (i.e., the potentially useful knowledge produced from the exploration/experimentation process itself). Hargadon and Sutton (1999), for instance, in analyzing the specific internal functioning of IDEO, the world renowned design firm, insisted on the contribution of those "secondary" ideas to the sparking and fuelling of new innovative initiatives and projects.
At this stage of the ideation process, we must identify the active units in the idea generation/conversion processes. Generating and converting ideas is essentially a socio-cognitive process and construction (Callon, 1999). If the original spark is more than often individual, the first validation and valuation of the idea comes from a small, situated group of informal "partners in crime", invited by the first "ideator" to react, comment, and contribute to the idea. In their article in this issue, Cummings, Bilton, and ogilvie (2015), emphasize that creativity in organizations is more than just coming up with a new idea: it must involve action beyond the generation of an idea, which they call "creativitying". Creativitying is group process and an action-embedded creativity.

Then, a defining and critical phase of translation and seduction begins, where the original "ideators" try to convince others of the newness, relevance, and value of the idea. At the same time, they need to foster reactions, criticisms, challenges, enrichments, and contributions from more and more partners. One of our studies in the video game industry (Cohendet et al., 2011), and many other contributions in the literature, emphasize the active and central role of "knowing communities" in this essential phase of the idea management process. Knowing communities share, challenge, and assemble bits and pieces of knowledge around a common object of interest, be it a practice, an emerging paradigm, or the construction of a new frame of understanding in a creative field. They act as an active repository of cognitive and practical resources that feeds not only the exploratory capabilities of the firm, but also its exploitation activities. The members of these communities (for instance, the Ubisoft game designers described in Cohendet \& Simon, 2007) have at the same time one foot in the cognitive construction of new ideas, and another one in the innovative projects of the firm. They lie at the best position possible to feedback ideation (exploratory) processes with the elements of knowledge acquired in (exploitation) processes in projects. These communities also compensate for the possible local limitation of resources by connecting to other external communities of knowledge from which they can import relevant elements to enrich their creative explorations and conversion of idea. They represent far more than a passive repository of knowledge. Rather, they act as an active device of exploration, exploitation, and renewal of the "creative slack" (Cohendet \& Simon, 2007) that will influence the strategic innovation pathways of the organizations in the future. 


\section{Introduction to the Special Issue on Creativity in Innovation}

\section{Patrick Cohendet and Laurent Simon}

Based on the literature on the management of ideas for innovation and our own studies, Table 1 synthesizes the components and activities involved at the three stages of the idea-development process. The starting point is to acknowledge that ideas should be considered as unfolding, open-ended processes that need to be managed in three main steps: i) the generation of the idea, ii) the conversion of the idea (i.e., looking for its consolidation and validation/valuation), and iii) the execution of the idea through the mobilization or organizational resources and processes (Hansen \& Birkinshaw, 2007). The activities at the three stages differ significantly. The first stage is exploratory and aims at generating new insights through knowledge association and recombination. It can involve free exploration or a more disciplined approach using specific methods. The second stage is essentially social and aims at convincing other actors to contribute to the validation and consolidation of the idea. The third stage aims at translating the idea into a value proposition relevant for the organization, and to convince the hierarchy to endorse the idea. The main actors - or "active units" - evolve along the process. Where individuals are generally at the origin of the idea, knowing communities play an essential role in the consolidation and validation phase. At the last phase, formal positions take over and are coordinated by the hierarchy in formal project mode. As mentioned earlier, this idea-development process needs to be enriched by very specific cognitive artefacts, especially at the conversion phase. The manifesto

Table 1. Untangling the idea-development process

\begin{tabular}{|c|c|c|c|}
\hline & The Spark & The Social Construction & The Landing \\
\hline Focus & Idea generation & Idea conversion & $\begin{array}{l}\text { Idea execution (Hansen \& } \\
\text { Birkinshaw, 2007) }\end{array}$ \\
\hline Main Activities & 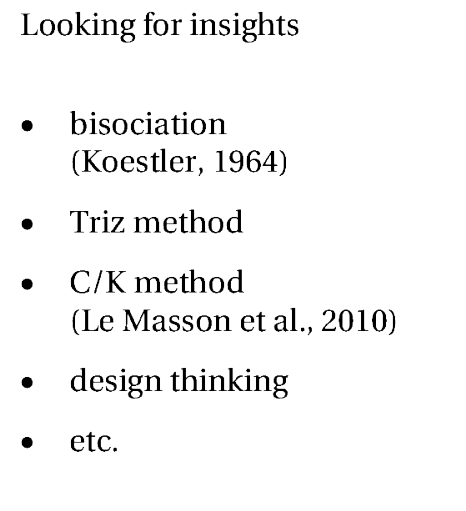 & $\begin{array}{l}\text { Sensemaking (Weick, 1995) } \\
\text { - } \text { sharing the idea } \\
\text { - looking for allies } \\
\text { - } \text { seducing } \\
\text { - convincing } \\
\text { - learning by intrusion } \\
\text { - building legitimacy } \\
\text { - etc. }\end{array}$ & $\begin{array}{l}\text { Sensegiving (Boland \& } \\
\text { Tenkasi, 1995) } \\
\text { - translating the idea into a } \\
\text { value proposition relevant } \\
\text { for the organization }\end{array}$ \\
\hline Active Units & - individuals & $\begin{array}{l}\text { knowing communities } \\
\text { (communities of practice, } \\
\text { epistemic communities, } \\
\text { etc.) } \\
\text { collectives }\end{array}$ & $\begin{array}{l}\text { - } \text { organization/hierarchy } \\
\text { - formal projects } \\
\text { - functional/operational } \\
\text { experts }\end{array}$ \\
\hline Cognitive Artefacts & $\begin{array}{l}\text { insights based on pre- } \\
\text { existing in-depth } \\
\text { knowledge and experience, } \\
\text { and research }\end{array}$ & $\begin{array}{l}\text { - } \text { manifesto } \\
\text { - codebook } \\
\text { - boundary objects / } \\
\text { prototypes }\end{array}$ & $\begin{array}{l}\text { validation through } \\
\text { valuation } \\
\text { - business model }\end{array}$ \\
\hline Cognitive Activities & - sensing & $\begin{array}{l}\text { - } \quad \text { seizing } \\
\text { - } \quad \text { sizing }\end{array}$ & $\begin{array}{l}\text { - reconfiguring } \\
\text { (Teece, 2009) }\end{array}$ \\
\hline
\end{tabular}




\section{Introduction to the Special Issue on Creativity in Innovation}

\section{Patrick Cohendet and Laurent Simon}

defines the spirit, the orientations, the constraints, and the values and identity of the idea. The codebook provides a "grammar of use" for the idea: it is literally a manual that explains how to use it and benefit from its value. The development of prototypes allows demonstration if the functioning and value of the idea or of some of its specific features. At the third stage, the ideadevelopment process must focus on developing a formal value proposition and business model to provide a convincing business case to the organization. This three-stage process is aligned with Teece's interpretation of the firm dynamic capabilities for innovation (2009), where the first issue for the organization is to generate some relevant insights, then to assess their value and select the most relevant one, and finally to reformat the idea as a formal project that is must be implemented in the pre-existing set of organizational resources and process, thus reconfiguring the organization to allow for the concrete development and actualization of the idea as a new product, service, or process.

\section{Managing the Tension between the Logic of Creation and the Logic of Production}

In a given organization, the traditional representation of the process of innovation is based on the classic sequential principle of the "stage-gate" (Cooper, 1990) (Figure 1). The first stage, the pre-conception stage, is dedicated to a process of idea generation. Then, through a sequence of stages and gates, an irreversible process of reduction of the variety of available options starts: the process of innovation follows different phases (conception, prototyping, demonstration, pro- duction, etc.). In each phase, ideas are put in competition: the ideas that are not selected are definitively discarded, and forgotten. Even if this approach proved its efficiency in terms of control of costs and respect of deadlines, it has, with regards to creativity, severe drawbacks: it aims at concentrating "thematic" creativity at the early stages of the process and discourages significant creativity at the later stages. As Egidi (1996) put forward, at each gate, there is some "incomplete knowledge and there is a need to complete it by recreating its missing components". The classical stage-gate process also entails two major risks: the first risk is to definitively discard an idea that did not seem mature enough at the moment of the decision, but that eventually would have had the potential of being a real breakthrough after additional work and feedback. The second risk is to select and commit to an idea that eventually will prove to be a poor one. Often, in such cases, it is too late to reconsider a process that has taken an irreversible path.

A major lesson learned from creative industries (Pixar, Google, Ubisoft, Whirlpool, Philips, Siemens, 3M, etc.) is that, contrary to traditional industries (where the process of idea generation and the process of project management tend to be sequential), the process of idea generation and the process of management of innovative projects in creative industries are run in parallel. They mutually feed each other (e.g., Tennant-Snyder \& Duarte, 2008). "Exploitation and exploration tend to be unfolded in an organically intricate and complementary way where they constantly fuel each other" (Cohendet \& Simon, 2007). The process of idea generation
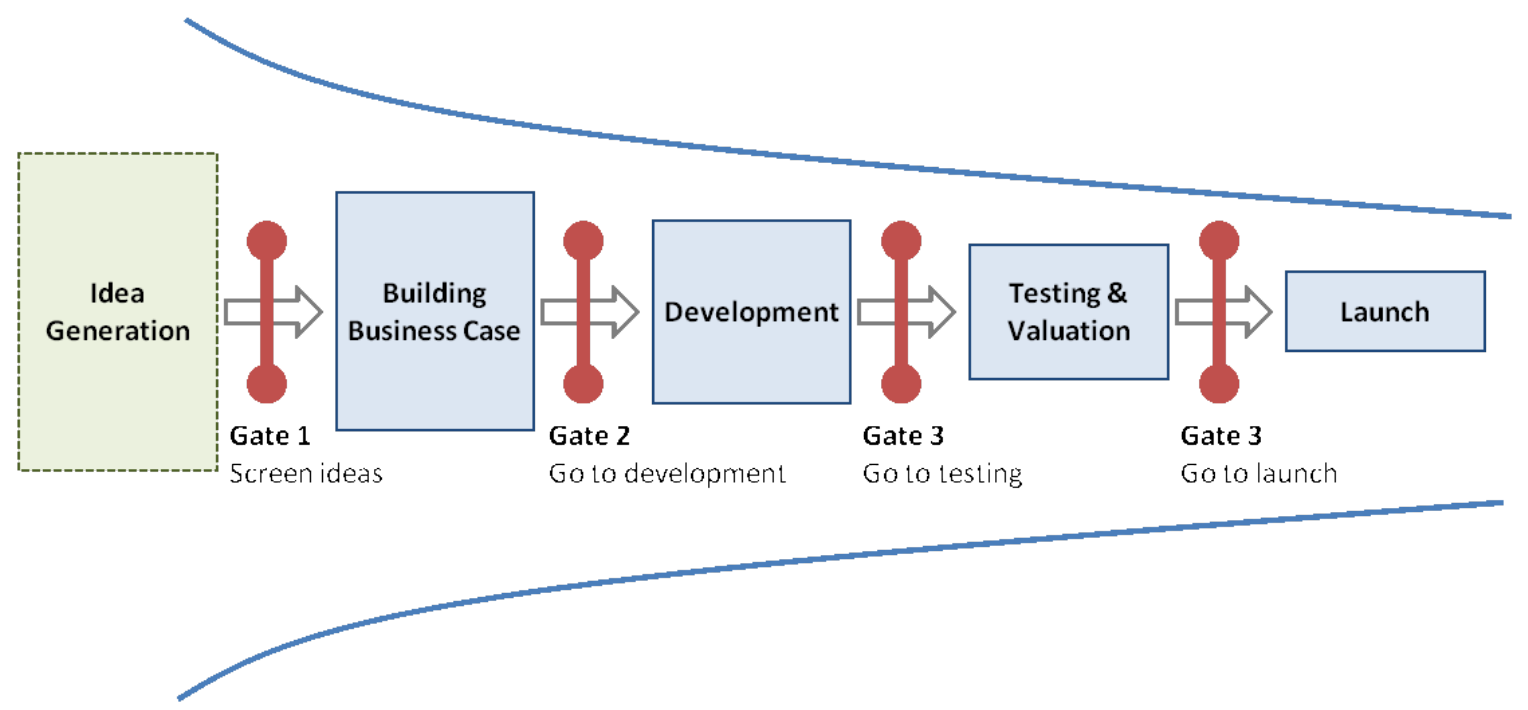

Figure 1. The "classic" process of staging and gating of a project 


\section{Introduction to the Special Issue on Creativity in Innovation}

\section{Patrick Cohendet and Laurent Simon}

assures the sustained creativity of the firm. Along this process, ideas are developed, nurtured, enriched, etc. as explained in the above section.

These "dual" dynamics of two main processes need subtle coupling and decoupling phases that must be orchestrated by an adequate process of knowledge management (Figure 2). Here, the main challenge for knowledge management is to ensure a dynamic relationship between two heterogeneous frames of references. On the one hand, ideation processes are essentially fed and nurtured by communities. These processes are informal and merely divergent and somehow chaotic, which implies that the classic means of control, such as contractual schemes of incentives, are irrelevant. What matters for agents involved in these ideation processes is the recognition of their contribution to the building of ideas (reputation), and intrinsic motivation. On the other hand, classic innovation processes, which are based on project teams, are mostly managed by the hierarchy, focusing on the convergence on value generation and actualization. These are mostly formal processes. To be consistent, the dynamic of these creative powerhouses supposes that both processes are to be constantly mutually enriched. This role mostly belongs to management, in charge of implementing various socio-cognitive transversal practices and processes to harness the idea generation dynamic to innovative projects. In the wide array of options possible, we can mention encouraging boundary spanners and knowledge brokers, designing technical cognitive platforms, and fostering and supporting communities. This area opens an extremely rich research agenda for academics and practitioners as well.

In the case of the conception of new artistic and acrobatic performance at Cirque du Soleil, it appears clearly that most efforts are inspired by a convergence on a common artistic vision, and at the same time a constant concern of consolidating multiple constraints of aesthetic value, physical prowess, and risk assessment. The reconciliation of these tensions is only possible through a constant back-and-forth process between the convergence of the innovative process and the divergence of the new ideas originating in the common rich experiences of all the stakeholders. In this regard, mobilizing multiple views and voices on ideas, and staging debates and conflicts, appears as a very efficient way to reach an optimal agreement for the enrichment and concretization of ideas. As the project progresses to-

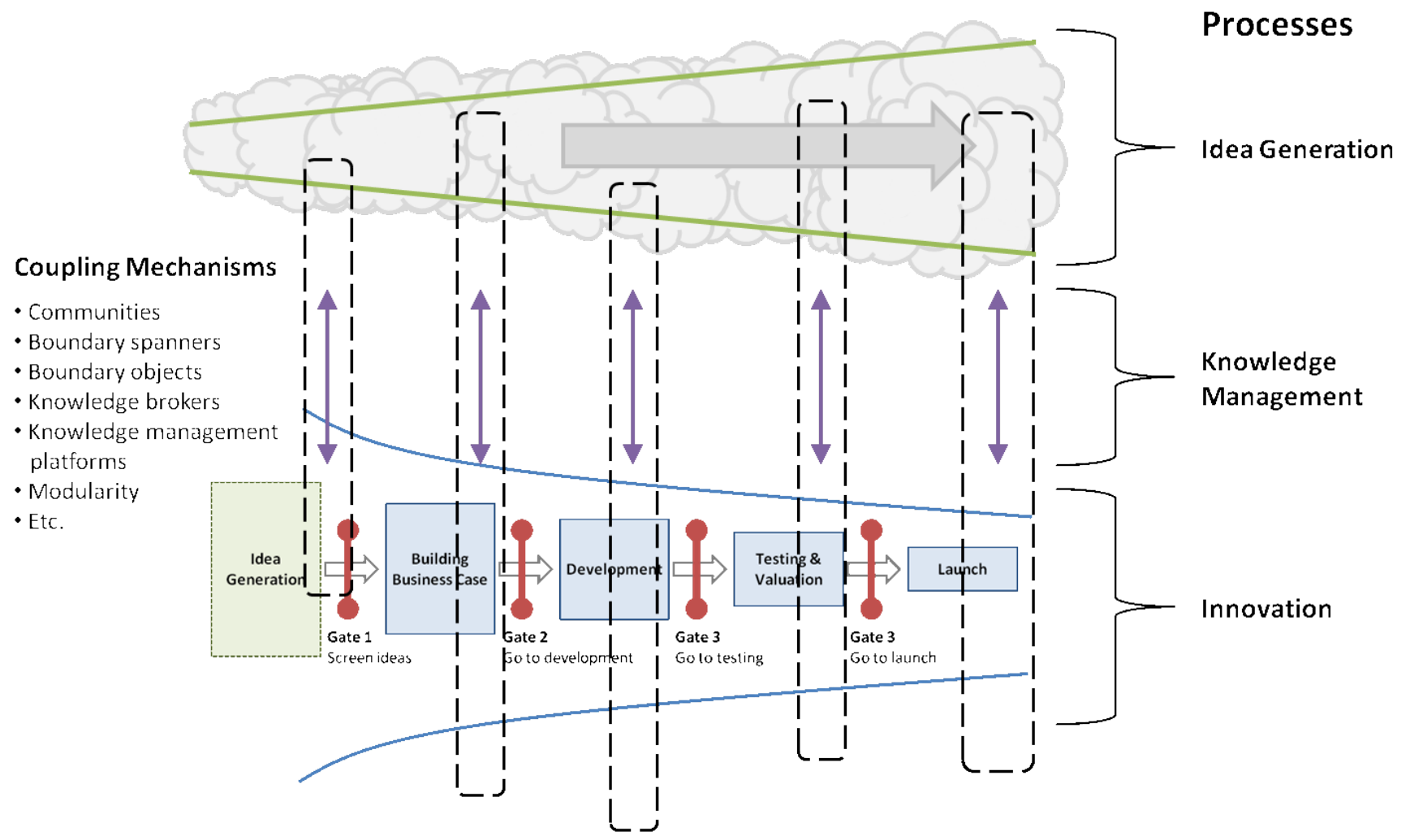

Figure 2. Coupling and decoupling ideation processes and innovation processes 


\section{Introduction to the Special Issue on Creativity in Innovation}

\section{Patrick Cohendet and Laurent Simon}

wards a stabilized framework for a new Cirque act, the many discussions are formally recorded in the knowledge base of the organization, and informally stored in the memory of individuals and of the community through stories and souvenirs, contributing to the accumulation of a creative reservoir (or "creative slack") for future insights and endeavours.

Essentially, nurtured by the creative communities, the fundamental element of the ideation process is the creative reservoir. The remarkable characteristic of the process is the formation of a creative reservoir viewed as a "repertoire of creative opportunities" that contributes by guiding the choice of future projects for the growth of the firm. The creative reservoir is shaped by the culture of the firm and is essentially understandable through the jargon of the organization. This parallels the analysis of Penrose, in which previously utilized managerial resources become "slack", and these "unused productive services are, for the enterprising firm, at the same time a challenge to innovate, an incentive to expand, and a source of competitive advantage" (Penrose 1959). In line with Penrose's vision, the firm that has accumulated a creative reservoir is better prepared than any other organization to derive a benefit from the creative potential of the reservoir. Because of these idiosyncrasies, it is much cheaper to valorize the reservoir within the firm that holds it than through any other organization (including through any isolated communities). Some may argue that the creative reservoir appears as a cushion of redundancy that is costly to maintain. The specific conditions of formation of the creative reservoir in creative companies rely on the functioning of quasi-autonomous communities that naturally produce and conserve the knowledge in their domain of specialization at negligible costs. They offer strong guarantees of the efficiency of maintaining the creative reservoir at low costs. The reservoir is not "possessed by the firm". It is essentially "delegated" to the communities.

To sum up, the traditional vision in management considers new ideas as preformatted "black boxes" (which can come either from outside or inside of the organization) containing well-described pieces of knowledge. What matters for the organization is the potential economic value of the new ideas that guides at each step of the stage-gate process the selection procedures of the managers. More precisely, in the traditional vision, the first step of the process is generally the phase of gathering the maximum number of ideas (using methods such as brainstorming). Then, through a "funnel" process shaped by a sequential "go, no go" procedure, the number of competing ideas is progressively trimmed: "no go ideas" that are not mature enough are generally discarded, and only a small number of "go ideas" pass the various gates before being transformed into some innovative output for the organization. Through this approach, many potentially creative ideas, which did not have time to mature, are definitely eliminated. The risk of killing creativity in pursuit of short-term efficiency is high. The story of IREQ, described in this issue by Raouf Naggar (2015), is a remarkable case of an organization that, after having observed many cases of "lost creative opportunities", has entirely rethought its ideation processes through constant coupling and decoupling between the management of ideas and the management of innovative processes. This today serves as a starting point to re-articulate capabilities in order to provide the organization with disruptive proposals.

\section{Managing Disruptive Innovation to Renew a Traditional Industry}

In times of turmoil and crisis, organizations and industries are challenged to reinvent themselves. Through an insider view on the creation of the Swatch, Gilles Garel (2015) illustrates in this issue how a strategy for disruption should bet on deep, first-hand knowledge of the industry, focused explorations, passion, and smart ingenuity. As demonstrated by Christensen (1997), disruption does not necessarily come from more technology, but through a subtle dialog between consumer's knowledge and an unforgiving value-analysis of the different components of the industrial chain, integrated in new business models and strategies. Aligning the core functions and structure of the product or service with the use and expectations of the customer requires a willingness to rethink the organization and the industry down to its roots. In terms of method, the cases of the Swatch, or of Tesla cars, or the iPod, show that successful, entrepreneurial innovators develop a dual capability. On one hand, they project and explore in depth and in detail some "ideals", visions of what the perfect answer to the customer's needs could and should be; on the other hand, in connection with the vision, they investigate varied knowledge bases, and then combine the most promising pieces in new concepts and solutions. Because they arise from a deep knowledge of the product and production methods, disruptive innovations usually emerge from the shop floor up to middle-management. Thus, they are made possible also only by the "enactment" of bottom-up proposals by top management, who should be humble enough and daring enough to reconsider their main strategy and reinvent their business. 


\section{Introduction to the Special Issue on Creativity in Innovation}

\section{Patrick Cohendet and Laurent Simon}

\section{Conclusion}

To echo Gary Hamel's call (2008) and Henry Mintzberg's concern (2015), to address the ever-accelerating complexity of the world we live in, organizations need to be reinvented as creative powerhouses, with a higher mission based on the end users' needs and expectations. This reinvention has to be centered and focused on the development of collective and collaborative, open-ended creative capabilities. We need to reclaim the organic side of organizations, as playgrounds for communities, garden for ideas, and dynamic reconnections to larger ecosystems. Our modest view on this, and a lesson from the different cases in this special issue, is that we collectively need to: i) rethink structures around open and transversal forms; ii) reformat processes by putting in tension the exploration of projected values, risk, and ideas; and iii) reboot culture by assessing and cultivating the cognitive work and the interplay of individual talents and communities, in dialog with hierarchy and markets (Adler, 2001, 2015) as the actual identity of the firm. We need to rethink and reinvent management. It is not a luxury; it is a necessity, and an emergency.

\section{References}

Adler, P. S. 2001. Market, Hierarchy, and Trust: The Knowledge Economy and the Future of Capitalism. Organization Science, 12(2): 215-234. http://dx.doi.org/10.1287/orsc.12.2.215.10117

Adler, P. S. 2015. Community and Innovation: From Tonnies to Marx. Organization Studies, 36(4): 445-471.

http://dx.doi.org/10.1177/0170840614561566

Altshuller, G. S. 1984. Creativity as an Exact Science. New York, NY: Gordon \& Breach.

Birkinshaw, J., Bouquet, C., \& Barsoux, J. L. 2012. The 5 Myths of Innovation. MIT Sloan Management Review, 52(2): 43-50.

Block, Z., \& MacMillan, I. C. 1993. Corporate Venturing. Boston, MA: Harvard Business School Press.

Boland Jr, R. J., \& Tenkasi, R. V. 1995. Perspective Making and Perspective Taking in Communities of Knowing. Organization Science, 6(4): 350-372.

http://dx.doi.org/10.1287/orsc.6.4.350

www.timreview.ca

\section{About the Authors}

Patrick Cohendet is a Professor in the Department of International Business at the HEC Montréal business school in Montreal, Canada, where he is also the Co-Director of Mosaic, the Creativity \& Innovation Hub. His research interests include the economics of innovation, knowledge management, and the economics of knowledge and creativity. He is the author of numerous articles and books including $L a$ Gestion des connaissances: firmes et communautés de savoir (2006) and The Architectures of Knowledge: Firms, Capabilities and Communities (2004). He was principal investigator of numerous research projects at BETA, a research lab at the University of Strasbourg, France, studying the economic and social impact of new technologies. He has conducted a series of economic studies on innovation for different firms and organizations, notably for the European Commission, the OECD, the Council of Europe, and the European Space Agency.

Laurent Simon is an Associate Professor in the Department of Entrepreneurship and Innovation at the HEC Montréal business school in Montreal, Canada, where he is also the Co-Director of Mosaic, the Creativity \& Innovation Hub. His current research focuses on characterizing the management of techno-creative projects and the study of creative environments and practices, the management of creative projects, creative communities, "creative cities", and the determinants of creativity in innovation management.
Brown, T. 2014. Change by Design. New York: HarperCollins.

Callon, M. 1999. Le réseau comme forme émergente et comme modalité de coordination: le cas des interactions stratégiques entre firmes industrielles et laboratoires académiques. In $\mathrm{M}$. Callon, P. Cohendet, N. Curien, J.-M. Dalle, F. Eymard-Duvernay, D. Foray, \& E. Schennk, Réseau et coordination: 13-64. Paris: Economica.

Capdevila, I., Cohendet, P., \& Simon, L. 2015. Establishing New Codes for Creativity through Haute Cuisine: The Case of Ferran Adrià and elBulli. Technology Innovation Management Review, 5(7): 25-33. http://timreview.ca/article/911

Caves, R. E. 2000. Creative Industries: Contracts between Art and Commerce. Cambridge, MA: Harvard University Press.

Christensen, C. M. 1997. The Innovator's Dilemma. Boston, MA: Harvard Business School Press.

Christensen, C. M., \& Raynor, M. E. 2003. Why Hard-Nosed Executives Should Care about Management Theory. Harvard Business Review, 81(9): 66-75. 


\section{Introduction to the Special Issue on Creativity in Innovation}

\section{Patrick Cohendet and Laurent Simon}

Cohendet, P., \& Simon, L. 2007. Playing across the Playground: Paradoxes of Knowledge Creation in the Video-Game Firm. Journal of Organizational Behaviour, 28(5): 587-605. http://dx.doi.org/10.1002/job.460

Cooper, R. G. 1990. Stage-Gate Systems: A New Tool for Managing New Products. Business Horizons, 33(3): 44-54. http://dx.doi.org/10.1016/0007-6813(90)90040-I

Cowan, R., David, P., \& Foray, D. 2000. The Explicit Economics of Knowledge Codification and Tacitness. Industrial and Corporate Change, 9(2): 211-253. http://dx.doi.org/10.1093/icc/9.2.211

Cummings, S., Bilton, C., \& ogilvie, d. 2015. Toward a New Understanding of Creative Dynamics: From One-Size-Fits-All Models to Multiple and Dynamic Forms of Creativity. Technology Innovation Management Review, 5(7): X-Y. http://timreview.ca/article/ZZZ

De Bono, E. 1971. Lateral Thinking for Management. Harmondsworth: Penguin Books.

Drazin, R., Glynn, M. A., \& Kazanjian, R. K. 1999. Multilevel Theorizing about Creativity in Organizations: A Sensemaking Perspective. Academy of Management Review, 24(2): 286-307. http://dx.doi.org/10.5465/AMR.1999.1893937

Egidi, M. 1996. Routines, Hierarchies of Problems, Procedural Behaviour: Some Evidence from Experiments. In K. J. Arrow, E. Colombatto, M. Perlman, \& C. Schmidt (Eds.), The Rational Foundations of Economic Behaviour: 303-333. New York: Martin's Press.

Eikhof, D. R., \& Haunschild, A. 2007. For Art's Sake! Artistic and Economic Logics in Creative Production. Journal of Organizational Behavior, 28(5): 523-538.

http://dx.doi.org/10.1002/job.462

Furr, N., \& Dyer, J. 2014. The Innovator's Method: Bringing the Lean Startup Into Your Organization. Boston, MA: Harvard Business Press.

Garel, G. 2015. Lessons in Creativity from the Innovative Design of the Swatch. Technology Innovation Management Review, 5(7): 34-40. http://timreview.ca/article/912

Govindarajan, V., \& Trimble, C. 2005. Building Breakthrough Businesses within Established Organizations. Harvard Business Review, 83(5): 58-68.

Hamel, G. 2008. The Future of Management. Boston, MA: Harvard Business Review Press.

Hansen, M. T., \& Birkinshaw, J. 2007. The Innovation Value Chain. Harvard Business Review, 85(6): 121-130.

Hargadon, A., \& Sutton, R. I. 1999. Building an Innovation Factory. Harvard Business Review, 78(3): 157-66.

Howe, J. 2008. Crowdsourcing: How the Power of the Crowd Is Driving the Future of Business. New York: Random House.

IBM. 2010. Capitalizing on Complexity: Insights from the 2010 IBM Global CEO Study. Somers, NY: IBM.

Koestler, A. 1964. The Act of Creation. London: Hutchinson \& Co.
Lampel, J., Lant, T., \& Shamsie, J. 2000. Balancing Act: Learning from Organizing Practices in Cultural Industries. Organization Science, 11(3): 263-269. http://dx.doi.org/10.1287/orsc.11.3.263.12503

Le Masson, P., Weil, B., \& Hatchuel, A. 2010. Strategic Management of Innovation and Design. Cambridge, UK: Cambridge University Press.

Mednick, S. 1962. The Associative Basis of the Creative Process. Psychological Review, 69(3): 220-232.

http://psycnet.apa.org/doi/10.1037/h0048850

Mintzberg, H. 2015. Rebalancing Society. San Francisco, CA: BerrettKoehler Publishers.

Naggar, R. 2015. The Creativity Canvas: A Business Model for Knowledge and Idea Management. Technology Innovation Management Review, 5(7): 50-58.

http://timreview.ca/article/914

Osborn, A. F. 1953. Applied Imagination. New York: Charles Scribner's Sons.

Penrose, E. 1959. The Theory of the Growth of the Firm. Oxford: Basil Blackford.

Roberts, J., \& Armitage, J. 2015. Luxury and Creativity: Exploration, Exploitation, or Preservation? Technology Innovation Management Review, 5(7): 41-49.

http://timreview.ca/article/913

Rothfeder, J. 2015. The Imagination Gap. strategy+business, April 20, 2015. Accessed July 1, 2015:

http://www.strategy-business.com/article/00334

Schumpeter, J. A. 1939. Business Cycles, Volume I. New York: McGrawHill.

Schumpeter, J. A. 1942. Capitalism, Socialism and Democracy. New York: Harper.

Simon, L. 2015. Setting the Stage for Collaborative Creative Leadership at Cirque du Soleil. Technology Innovation Management Review, 5(7): 59-65.

http://timreview.ca/article/915

Snyder, N. T., \& Duarte, D. L. 2008. Unleashing Innovation: How Whirlpool Transformed an Industry. New York: John Wiley \& Sons.

Styhre, A. 2006. Organization Creativity and the Empiricist Image of Novelty. Creativity and Innovation Management, 15(2): 143-149. http://dx.doi.org/10.1111/j.1467-8691.2006.00386.x

Teece, D. J. 2009. Dynamic Capabilities and Strategic Management: Organizing for Innovation and Growth. Oxford: Oxford University Press.

Verganti, R. 2013. Design Driven Innovation: Changing the Rules of Competition by Radically Innovating What Things Mean. Boston, MA: Harvard Business Press.

Weick, K. E. 1995. Sensemaking in Organizations, Volume 3. Thousand Oaks, CA: Sage.

Woodman, R. W., Sawyer, J. E., \& Griffin, R. W. 1993. Toward a Theory of Organizational Creativity. Academy of Management Review, 18(2): 293-321. http://dx.doi.org/10.5465/AMR.1993.3997517 